\title{
CORRESPONDENCE
}

\section{MAKING THE JOURNAL OF THE GEOLOGICAL SOCIETY OF INDIA MORE USEFUL AND INTERESTING}

The readership of journal comprises geoscience teachers, serving and retired professional geoscientists, research scholars, and post-graduate students. Therefore, every Number of JGSI should carry one of the following additional features, besides those being published presently, so that it meets the needs of one and all. The Editor may kindly invite learned geoscientists, academicians, within and outside India, to contribute Review Papers, Geotutorials, Comprehensive Bibliographies, Dissertation Abstracts, Editorials, Geoideas and Geoviews.

\section{State-of the-art Review Papers}

Although JGSI welcomes Review Papers, seldom do we find one getting published in the Journal. Some topics are: (1) Komatiites. (2) Geobotanical methods of mineral exploration. (3) Computer applications in the geosciences. The Fellows of the Geological Society of India should also be requested to suggest suitable topics.

\section{Geotutorials}

These are for the benefit of post-graduate students and research scholars. Some topics are: (1) Measurements of structural elements in metamorphic complexes. (2) Construction and interpretation of rare-earth element (REE) patterns. (3) Statistical analysis of geochemical data. Geoscience teachers and research supervisors should be requested to suggest suitable topics.

\section{Comprehensive Bibliographies}

These are intended for those who wish to pursue an in-depth study of a particular topic. Some topics are: (1) Komatiites. (2) Boninites. (3) Adakites. (4) Sanukitoids. (5) Carbonatites. (6) I-, S-, A-, M-, C-, and H-type granites. The Fellows of the Geological Society of India should also suggest the topics of their interest. These up-to-date bibliographies can be published in Society's website.

\section{Topics for Research}

These are to help post-graduate students to choose projects for research towards their Master's and Doctorate Degrees. Some topics are: (1) Geochemistry of monazite from the beach placers of India. (2) Rhenium-osmium geochronology of columbite-tantalite from the rare-metal pegmatite bodies of India. (3) Petrology and geochemistry of komatiites from the Antarghatta Belt, Karnataka, India. Eminent geoscientists with a proven record for high quality research should suggest topics of current interest.

\section{Dissertation Abstracts}

Those who have just been conferred the Master's (by Thesis) and Doctorate Degrees should be informed that the Abstracts of their Dissertations will be considered for publication in JGSI.

\section{Editorials}

Highly knowledgeable geoscientists, within and outside India, should be requested by the Editor to contribute Editorials on burning topics of the day, to JGSI.

\section{Geoideas}

The Fellows of the Geological Society of India who have some brilliant, bright, imaginative, creative, and innovative ideas, however speculative they might be, to solve some of the problems in the geosciences, should be encouraged to contribute their thoughts. They should also be requested to suggest ways to discover new ore-deposits.

\section{Geoviews}

The Fellows of the Geological Society of India should be requested to share their views on any contemporary and controversial problems in the geosciences.

Hyderabad S. VISWANATHAN 